\title{
The "Lawful Judge" - a Comparative Survey on the Allocation of Cases to Judges in South Africa and Germany ${ }^{1}$
}

\author{
By Hilke Thiedemann, Hamburg
}

Since 1994 South Africa has been a democratic state, governed in terms of the rule of law. The advent of a new constitutional order in 1994 had implications for the whole legal system. The most significant change, from a legal perspective, lay in the transition from the sovereignty of parliament to the supremacy of the constitution. The acceptance of a supreme constitution also entailed a new role for the South African judiciary. In particular, the courts were now empowered to review and set aside legislation. This new dispensation, designed to overcome the aftermath of apartheid, and the resulting increase of the courts' power raise anew the question of the independence of the judiciary.

The establishment of a new constitutional framework offers a unique chance to address contemporary problems and find adequate solutions for new societal phenomena. On the other hand, it enables the rethinking of established legal structures and practices. The drafters of the interim Constitution of $1994^{2}$ and the final Constitution of $1997^{3}$ borrowed from the experiences gained by other countries during the development of their constitutions. Among others, the experience of Germany with its constitution - the Basic Law (Grundgesetz) ${ }^{4}$ - had a significant impact during the deliberations on how to accomplish a new and just order in South Africa ${ }^{5}$. South Africa and Germany both have relatively young constitutions, designed to establish a new order, after pasts that were temporarily characterised by perversions of the previous legal order ${ }^{6}$. Both states now adhere to the principle of constitutionalism and are governed in terms of the rule of law.

This article is based on a study project submitted to the Faculty of Law of the University of Stellenbosch, South Africa, in the 2001 academic year in partial fulfilment of the requirements for the degree of Master of Laws.

Constitution of the Republic of South Africa Act 200 of 1993, date of commencement: 27 April 1994.

3 Constitution of the Republic of South Africa Act No. 108 of 1996 - hereafter "the Constitution".

4

Grundgesetz für die Bundesrepublik Deutschland, promulgated on 23. May 1949, BGBl. III/FNA $100-1$, as amended up to 11/26/2001.

5 See Fedtke, Die Rezeption von Verfassungsrecht - Südafrika 1993-1996 (2000), 86.

6 At the time of National-Socialism in Germany, the Weimar Constitution of 1919 was still in force. Although it provided for a democratic state order, its provisions were constantly circumvented, including, amongst others, the principle of the "lawful judge", which was contained in Article 105 
The rule of law entails, amongst other things, the guarantee of an independent judiciary that is free from any actual or perceived influence, as part of the separation of powers doctrine. One of the features of an independent judiciary in German law is the guarantee to have one's case decided by a "lawful judge", which is entrenched in article 101 (1) sentence 2 of the Basic Law ${ }^{7}$. This provision guarantees that the allocation of a judge to a case is made in terms of objective criteria. As with the guarantee of the independence of judges, this provision seeks to prevent improper interference in the administration of justice. It is further aimed at protecting and enhancing the confidence of the litigants and the public in the impartiality and objectivity of the courts ${ }^{8}$.

The South African Constitution does not explicitly recognize the notion of a "lawful judge". It does, however, provide for an independent judiciary in section 165 . In the light of the injustices of South Africa's past, a past that was characterized by the deprivation of certain societal groups of their rights and the abuse of the law for political purposes, attention should be paid to the question of whether there actually exists an effective mechanism to prevent potential manipulations of the outcome of cases by the courts (internally) or any other person or entity (externally). This also forms part of the deliberation on how to overcome the persisting notion that the South African judiciary lacks the necessary degree of independence. Recently, this problem has been highlighted by the United Nations Commissioner on Human Rights in a report on the South African legal system?

This article aims to describe the guarantee of the "lawful judge" in German law and compare this principle with the practice of allocation of court cases in South Africa. After an explanation of the scope and implications of the principle in German law, the need for its adoption into the South African legal system will be pointed out. An overview of the recent developments in South Africa in the area of judicial independence and court organization will be given, followed by a brief analysis of the possible reasons why the principle has not found reception in the South African Constitution. An attempt will then be made to

sentence 2 of the Weimar Constitution. The independence of judicial decisions was undermined through criticism of judgments and barely concealed orders from the executive to the judges. See for details Müller, Hitler's Justice - The Courts of the Third Reich (1991); Wagner, Die Umgestaltung der Gerichtsverfassung und des Verfahrens- und Richterrechts im nationalsozialistischen Staat, in: Die deutsche Justiz und der Nationalsozialismus, vol. I (1968), p. 189 ff., (206 ff., $210 \mathrm{ff}$.).

7 What is meant by the expression "lawful judge", as it will be used throughout this text, is a judge who is allocated to a particular case in accordance with the provisions of article 101 (1) sentence 2 of the Basic Law, as well as the other objective criteria specified in the statutes or rules regulating the allocation of judges.

Träger, Der gesetzliche Richter, in: Festschrift für Wolfgang Zeidler vol. I (1987), 124.

The report strongly criticized the independence of the South African judiciary in particular; see UN special rapporteur's report on SA legal system (Param Cumaraswamy), $57^{\text {th }}$ session, Item 11 (d), E/CN.4/2001/65/ Add.2, see under www.unhchr.ch. 
determine if the principle can be derived from the existing provisions of the Constitution. Finally, an argument will be made in favour of integrating the principle into South African law. The article concludes with some proposals for legislative reform to incorporate the principle of the "lawful judge" by means of a statutory provision.

\section{The guarantee of the "lawful judge" in German law}

The idea of the "lawful judge" is not new in German law, but has an extensive constitutional history. The Constitution of 1849 (Paulskirchenverfassung), the Constitution of Prussia and the Constitution of the Weimar Republic of 1919 all contained provisions identical to the one in article 101 (2) of the Basic Law ${ }^{10}$. The evident circumvention of these provisions in the era of National-Socialism, however, made clear how important it is to ensure the effectiveness of this principle ${ }^{11}$.

\section{Constitutional context}

The principle of the "lawful judge" is contained in article 101 (1) sentence 2 of the Basic $\mathrm{Law}^{12}$, and is repeated verbatim in $\S 16$ sentence 2 of the Judicature Act ${ }^{13}$.

Article 101 of the Basic Law forms part of the provisions dealing with the judiciary and consists of two subsections:

Article 101 [Ban on extraordinary courts] ${ }^{14}$

(1) Extraordinary courts shall not be allowed. No one may be removed from the jurisdiction of his lawful judge.

(2) Courts for particular fields of law may be established only by a law.

The guarantee of the "lawful judge" in article 101 (1) sentence 2 of the Basic Law is included as part of provisions regarding the establishment of special courts ${ }^{15}$. Article 101

$\S 175$ (2) of the Paulskirchenverfassung of 1849 read as follows: "No one may be removed from the jurisdiction of his lawful judge. Extraordinary courts shall never occur."; Article 105 of the Weimar Constitution: "Extraordinary courts are not permitted. No one may be removed from the jurisdiction of his lawful judge. [...]".

11

Compare p. 56 of the report on the Constitutional Convent on Herrenchiemsee (10.-23.8.1948), chapter: "Die Rechtspflege".

12 The right to the "lawful judge" is today also provided for in numerous state constitutions in Germany.

13 Gerichtsverfassungsgesetz (GVG) as announced on 9th May 1975, as amended up to 22.8.2002, BGB1. III/FNA 300-2.

14

Excerpt of the English translation of the Basic Law, as published in: Basic Law for the Federal Republic of Germany by the Press and Information Office of the Federal Government of the Federal Republic of Germany, translated by Tomuschat and Currie. 
(1) sentence 1 of the Basic Law prohibits, as a general rule, extraordinary courts that are established in deviation from statutory rules of competence ${ }^{16}$ for the purpose of adjudicating specific individual cases ${ }^{17}$. Article 101 (2) of the Basic Law in contrast allows the establishment of courts for particular areas of law by means of parliamentary legislation ${ }^{18}$. Despite the structure of article 101 of the Basic Law, both provisions are seen as concretizations of the principle of the "lawful judge" 19 .

Article 101 (1) sentence 2 of the Basic Law is applicable to every "judge" who performs the task of adjudication - professional judges as well as lay judges. The formulation "jurisdiction of his "lawful judge" requires the existence of a statutory order of competence. Somebody is "removed" from his "lawful judge" if the judge who is determined to be legally competent to hear his case is prevented or impeded from hearing and deciding the case by another public authority ${ }^{20}$. The guarantee of the "lawful judge" requires an objective mechanism or general norm to help determine, as precisely as possible, which judge is competent to hear a particular case ${ }^{21}$. The competent judge need not be designated by name, but must at least be determinable through the application of abstract norms.

These provisions have their origin in the negative experiences during the era of National Socialism when so-called Sondergerichte were deliberately created by the executive to persecute political opponents. See for a detailed description of the administration of courts at that time: Müller, supra note 6 .

When reference is made in this text to the "statutory rules of competence" or "the order of competence", this will refer to the collection of rules that determine not only which court is competent to hear a particular case (equivalent to the South African rules of jurisdiction) but also, within a particular court, which adjudicating bodies or judges will be competent to adjudicate a particular case.

BVerfGE (Decisions of the Federal Constitutional Court / Bundesverfassungsgerichtsentscheidungen) 2, 213 (223); 8, 174 (182); 10, 200 (212); 14, 56 (72); Roth, Das Grundrecht auf den gesetzlichen Richter (2000), 20.

They replace the courts that would generally have jurisdiction in that field. Their jurisdiction must be determined in advance in a general and abstract way through a statute. Examples are: labour courts, juvenile courts, social security tribunals, professional tribunals, disciplinary tribunals for judges or for civil servants and shipping courts; compare Kunig, in: von Münch/Kunig, Grundgesetz-Kommentar, vol. 3, $3^{\text {rd }}$ ed. (1996), Art. 101 at no. 41 f.; Degenhart, in: Sachs, GrundgesetzKommentar, $3^{\text {rd }}$ ed. (2003), Art. 101 at no. 24; Schmidt-Bleibtreu, in: Schmidt-Bleibtreu/Klein, Kommentar zum Grundgesetz, $9^{\text {th }}$ ed. (1999), Art. 101 at no. 14.

Disregard of the provisions also constitutes an infringement of the principle of the "lawful judge". See for art. 101 (2): BVerfGE 22, 42 (48); 27, 355 (364); Classen, in: v.Mangoldt/Klein/Starck, Bonner Grundgesetz, vol. 3, $4^{\text {th }}$ ed. (2001), Art. 101 Abs. 1 at no. 4. For art. 101 (1) sent. 1: Degenhart, Gerichtsorganisation, in: Isensee/Kirchhof, Handbuch des Staatsrechts vol. III, $2^{\text {nd }}$ ed. (1996), § 75 at no. 17; Roth, supra note 17, 21; Sowada, Der gesetzliche Richter im Strafverfahren (2002), 136. 
The principle seeks to prevent every infringement with the administration of justice that disregards the legal order of competence. It aims to ensure a fair trial before an independent judge, who is allocated to a case without regard to the persons or the particular matter involved. Together with articles 92 (assignment of judicial power to judges) and 97 of the Basic Law (independence of judges), article 101 of the Basic Law thus gives effect to the principle of separation of powers, entrenched in article 20 (2) sentence 2 of the Basic Law, and the rule of law. The interplay of these provisions warrants the safeguard and maintenance of an administration of justice that is characterized by the rule of law.

\section{The concept of the "lawful judge"}

\section{a) From an institutional guarantee to an individual right}

The principle of the "lawful judge" aims at preventing ad hoc and ad personam allocations of cases, by providing for an objective statutory determination of which judges are competent $^{22}$. It aims at giving effect to the principle of the rule of law in the crucial area of judicial organisation ${ }^{23}$. Originally, the principle that no one may be deprived of his "lawful judge" only required compliance of the courts with the respective rules of competence and was thus primarily directed against external interference by the executive ${ }^{24}$. It was believed that the independence and neutrality of the administration of justice would be called into question if parliament, the government or other entities could hinder a judge from his decision-making, assert influence upon a decision or debar a judge from a process. The same problems would arise if courts could be composed arbitrarily from case to case in order to achieve a particular outcome in a matter. The guarantee of the "lawful judge" therefore aims at preventing the danger that the judicial organs are unduly influenced, be it from whatever source ${ }^{25}$.

For the individual, the principle provides him with a right that can be asserted by means of a constitutional complaint ${ }^{26}$. The litigant has a right that the case in which he is involved is decided by "his" or "her" judge, a judge selected as competent on the basis of objective

BVerfGE 17, 294 (299); 25, 336 (346); 82, 159 (194); also compare Benda/Maihofer/Vogel, Handbuch des Verfassungsrechts der Bundesrepublik Deutschland, $2^{\text {nd }}$ ed. (1994), § 33 at no. 55.g

BVerfGE 40, 356 (361); Träger, supra note 8, 124.

So-called "Kabinettsjustiz". See Barbey, Der Status des Richters, in: Isensee/Kirchhof, Handbuch des Staatsrechts, vol. III, $2^{\text {nd }}$ ed. (1996), $§ 74$ at no. 60.

26

Badura, Staatsrecht, $2^{\text {nd }}$ ed. (1996), 582 at $\mathrm{H} 24$.

Art. 93 (1) Nr. 4 a) Basic Law. See Roth, supra note 17, 16. 
criteria $^{27}$. The right applies to every party involved in judicial proceedings, individuals as well as juristic persons ${ }^{28}$.

Besides guaranteeing a legally competent judge, the principle of the "lawful judge" has also developed into a guarantee that such judge must also conform to all other constitutional and statutory requirements ${ }^{29}$. This entails, firstly, that an infringement of a "functional norm", such as article 97 of the Basic Law which guarantees the independence of judges, can be asserted by an individual to be an infringement of article 101 (1) sentence 2 of the Basic Law $^{30}$. Secondly, in order to ensure objective, fair and impartial proceedings, the principle requires provision to be made for the recusal of judges who do not display impartiality ${ }^{31}$.

The principle of the "lawful judge" does not, however, afford a right to a capable or qualified judge ${ }^{32}$. Nor does Article 101 (1) sentence 2 of the Basic Law provide the right to have a case decided by a judge that is particularly familiar with the field of law concerned. As the lack of such capabilities does not constitute an infringement of the administration of justice, they are not covered by the scope of the provision ${ }^{33}$. This is based on the notion that an independent judge who is determined without regard of the parties or the case is, after all, the best judge that the parties can get. The right to the "lawful judge" only guarantees the decision of the "correct" judge in terms of competence and the law.

BVerfGE 17, 294 (299) = NJW (Neue Juristische Wochenschrift) 1964, 1020; BVerfGE 40, 356 $(360)=$ NJW 1976, 283.

The right can also be asserted by the State in its capacity as party in judicial proceedings, BVerfGE 6, 45 (49); Classen, in: v.Mangoldt/Klein/Starck, supra note 19, Art. 101 Abs. 1 at no. 7.

BVerfGE 82, 286 (298), consistent practice.

Barbey, supra note $24, \S 74$ at no. 61 f.; criticized by: Kunig, in: von Münch/Kunig, supra note 18, Art. 101 at no. 18 and Bettermann, Der gesetzliche Richter in der Rechsprechung des Bundesverfassungsgerichts, AöR 94 (1969), 263 (271).

BVerfGE 21, 139 (146). See $\S 42$ ZPO and $\S 24$ StPO. In contrast to this, the mere possibility of self-recusation by the judge is insufficient, Kunig, in: von Münch/Kunig, supra at no. 18, Art. 101 at no. 17 .

Wipfelder, Die Rechtsprechung des Bundesverfassungsgerichts zu Art. 101 Abs. 1 Satz 2 GG, VBlBW 1982, 33 (43). 
Article 101 (1) sentence 2 of the Basic Law is aimed at ensuring that the legislative and executive organs, as well as the judicial organ itself, do not exercise undue influence on the judicial function.

The provision requires the establishment of a statutory order of competence. It therefore places an obligation on the legislator to establish rules of competence. These rules must, as with statutes, be of general and abstract nature, rather than be specifically focussed at particular cases or situations. The rules must be as definite and precise as possible ${ }^{34}$. The requirements of precision can still be fulfilled if the rules make use of indefinite terms (unbestimmte Rechtsbegriffe), as long as any problems of interpretation that may arise can be solved by conventional juristic interpretation methods ${ }^{35}$.

However, a concrete determination of who the competent judge or adjudicating body within the court should be and what such court's composition should be cannot be achieved by means of a general statute. The diversity of jurisdictions and courts and the differences in size, number of judges and workloads of each court render it impossible to determine in a parliamentary statute all the minutiae of competence, down to the level of choosing specific judges $^{36}$. The statutory rules therefore need to be supplemented by internal court rules regulating the allocation of matters and the manner in which judges participate in the decision of cases. Only the fundamental rules of competence, such as those regulating the establishment of courts and court districts as well as the jurisdiction of courts, have to be regulated by the legislature ${ }^{37}$.

In addition, not only is the allocation of specific judges by the legislature practically unfeasible, it is furthermore not compatible with the guarantee of independence of the judiciary. Parliamentary regulation in this area would constitute infringement of the judicial sphere and therefore violate the principle of separation of powers. The manner in which individual judges participate in the adjudicating process must therefore, as a matter of necessity, be regulated by the courts themselves as an act of judicial "self-administration".

Established practice of the Federal Constitutional Court since BVerfGE 6, 45 (50). This restriction takes into account the difficulties in regulating unforeseen events in abstracts norms; it is an expression of the tension between legal certainty and practicability, Kunig, in: von Münch/Kunig, supra note 18, Art. 101 at no. 25.

BVerfGE 82, 286 (301 f.) = NJW 1991, 217 (219).

36

37

BVerfGE 17, 294 (299) = NJW 1964, 1020.

BVerfGE 19, 56 (60). This also includes the determination of the budget and of the necessary financial means for the offices of judges; Degenhardt, in: Sachs, supra note 18, Art. 101 at no. 6a. 
On the one hand, article 101 (1) sentence 2 Basic Law therefore imposes an obligation on the legislature to provide the fundamental rules of competence, while at the same time creating an obligation for the courts to supplement the statutory norms with objective principles of allocation (which are set out in a so-called "table of duties" (Geschäftsverteilungsplan) ${ }^{38}$. On the other hand, article 101 (1) sentence 2 Basic Law contains a prohibition against deviation from established rules of competences. In this respect, the provision is aimed at ensuring that the judiciary complies with the existing rules of competence. It prohibits any internal court actions that are aimed at circumventing rules of competence, i.e. ensuring that nobody may be deprived of his "lawful" judge by internal measures taken within the court structure ${ }^{39}$.

An infringement of article 101 (1) sentence 2 of the Basic Law renders a decision unconstitutional. Such a decision can be appealed against or otherwise challenged by means of the extraordinary remedy of a constitutional complaint ${ }^{40}$.

According to German jurisprudence a mere violation of procedural provisions (error in procedendo) does not constitute an infringement of the "lawful judge" principle, ${ }^{41}$ as this would, in effect, elevate the application of statutory law to constitutional level. A procedural error only leads to the annulment of the decision, if the error has potentially influenced the substance of the decision. As each judge and court is different, however, and as each court is entitled to make a decision which is independent of decisions reached in other courts (Germany not recognising the stare decisis principle), any granting of jurisdiction to a court, or composing of an adjudicating body, in a manner different to that prescribed by law can have a potential influence on the outcome of a decision ${ }^{42}$. However, not every accidental non-compliance with the rules of competence justifies the annulment of the decision. The German Federal Constitutional Court therefore usually only sets aside "arbi-

BVerfG, NJW 1995, 2703 (2704).

BVerfGE 3, 359 (364) with further references; BVerfGE 4, 412 (416); 82, 286 (298). Comp. Degenhart, Gerichtsorganisation, supra note $19, \S 75$ at no. 17. (Bundesverfassungsgerichtsgesetz, as announced on 11 Aug.1993, BGBl. III/FNA 1104-1; as amended up to 19.06.2001). 
trary decisions that can evidently not be upheld"43. The vagueness of this criterion has been subject to strong criticism ${ }^{44}$.

\section{Implications for court organisation}

Essentially, a judge is "lawful" if his competence is determinable by virtue of objective criteria. The effect of all the rules of competence - from statute down to the table of duties of a court - must be to provide a means of determining which specific judge/s must be allocated to a particular case. The purpose of these rules is to determine the competent judge - not only the competent court ${ }^{45}$. This has an effect on the court system and the internal structure of the courts. A determination of a competent judge must take place in several steps: firstly, the determination of the competent court and secondly the determination of the bench through an establishment of adjudicating bodies. Additional principles for the allocation of judges are necessary in the event of an overstaffing of adjudicating bodies.

Since it is impossible to determine specific competent judges in a statute, the legislature can only establish the fundamental rules of competence. It has to establish, amongst other things, regulations determining the jurisdiction of the courts as regards the subject, the local jurisdiction and the court instance ${ }^{46}$. Due to the existence of objective rules of jurisdiction, a plaintiff cannot simply choose a forum that he considers will be best suited to ensure a beneficial outcome for his case. This phenomenon of "forum shopping" is to a large extent avoided by the exclusive character of jurisdictions. The general rule is that courts are competent to hear a matter if the defendant resides in their area of jurisdiction, unless a

BVerfGE 29, 45 (49) with further references; BVerfGE 58, 1 (45); those will be decisions that directly concern the competence of the courts or particular judges, compare Classen, in: v.Mangoldt/Klein/Starck, supra note 19, Art. 101 Abs. 1, at no. 30; Leibholz/Rinck/Hesselberger, Art. 101 at no. 226.

Roth, supra note 17, 507 with further references; Kunig, in: von Münch/Kunig, supra note 18, Art. 101 at no. 46.

Compare Bettermann, Die rechtsprechende Gewalt, in: Isensee/Kirchhof, Handbuch des Staatsrechts, vol. III, $2^{\text {nd }}$ ed. (1996), $§ 73$ at no. 61.

These are provided for in the German Judicature Act (Gerichtsverfassungsgesetz) and the rules on civil procedure (Zivilprozeßordnung). A court has local jurisdiction when it is competent for the court district in which the case occurred; competence in substance is given when the nature of disputes falls into the substantial area of jurisdiction; functional competence describes the jurisdiction of a court as the proper instance in the hierarchy of courts, compare Thomas/Putzo, Zivilprozeßordnung, $21^{\text {st }}$ ed. (1998), Vorbem $\S 1$ at nos. 2-4. 
special rule of jurisdiction applies ${ }^{47}$. The underlying reason is that the defendant cannot be expected to travel to another forum; the plaintiff must bear the inconveniences of legal action before a court outside his area of residence - actor sequitur forum rei. The creation of special jurisdications is justified by reasons of practicability and close relation to the matter. In the event that more than one court is competent the plaintiff can choose between different fora; this is accepted in light of the underlying justification for special jurisdictions. In combination with each court's internal rules of competence they leave only a minimal scope for so-called "judge-shopping".

\section{b) Determination of the composition of adjudicating bodies}

An obligation is placed on the courts to establish rules for allocation of personnel and matters to adjudicating bodies, a so-called "table of duties" (Geschäftsverteilungsplan), in terms of $\S 21$ e GVG:

$\S 21$ e GVG [Function and competence of the presiding committee; allocation of duties] ${ }^{48}$

(1) The presiding committee determines the composition of the adjudicating bodies, appoints the investigating judges, regulates the substitution and assigns the duties. It makes these determinations before the beginning of the court term and for its duration. The president decides which adjudicative functions he performs. Every judge can be a member of several adjudicating bodies.

(2) Before the assignment of the duties, the judges that are not members of the presiding committee must be given opportunity to comment ${ }^{49}$.

(3) The determinations in terms of subsection 1 may only be amended during the course of the court term if this becomes necessary due to overload or insufficient employment of a judge or of an adjudicating body, or due to a transfer or permanent leave of specific judges. Before such an amendment, the presiding judge of the adjudicating body concerned must be given opportunity to comment.

(4) The presiding committee can order that a judge or an adjudicating body that has acted in a case remains competent after an amendment of the allocation of duties.

For the ordinary jurisdiction this is provided in $\S \S 12,13 \mathrm{ZPO}$ (Zivilprozeßordnung, promulgated on 09/12/1950, as amended up to 07/23/2002, BGB1. III/FNA 310-4); for juristic persons applies the general jurisdiction of the seat of the head office, $\S 17$ ZPO. Special jurisdictions apply e.g. for claims in rem (forum rei sitae), for the assets, for probate cases, at the place of performance ( $\S 20 \mathrm{ff}$. ZPO) or for a choice of jurisdiction of the parties ( $\$ 38 \mathrm{ZPO})$. The rules of the Administrative Courts (Verwaltungsgerichtsordnung) refer to these provisions in $\S 173$ VwGO.

If not indicated otherwise, cited legal texts have been translated into English by the author.

49

This constitutes an amendment to the previous version that only provided for the comment of presiding judges; the new regulation enhances the democratic legitimacy of the decision. 
(5) If a judge is allocated to another adjudicating body or if his area of competence is changed, he must, except for urgent matters, be given an opportunity in advance to comment.

$[\ldots]$

(9) The schedule of responsibilities of the court is to be laid open for inspection in the registry that is determined by the president or the supervising judge; publication is not required.

The presiding committee of the court is, by virtue of these provisions, entitled to assign subject matters to the existing adjudicating bodies. The decision as to the number of adjudicating bodies at a court is a prior budgetary decision made by the Ministry of Justice. In addition, the number of judges that are required to decide a case must be specified by statute $^{50}$. This number of judges may not be altered unless it is done in terms of the applicable statute. The presiding committee determines the composition of the adjudicating bodies. Because this allocation directly influences the judiciary, the principles of independence of the judiciary (Article 97 (1) Basic law) and separation of powers (Article 20 (2) sentence 2 Basic Law) require that it must be undertaken by the courts themselves as an act of internal "self-government" "51. The possibility of unavailability of judges for exceptional reasons such as e.g. illness, leave or the retirement of one or more judges, must be taken into consideration in advance ${ }^{52}$. The table of duties must also provide for an objective means of determining which of the judges will be recruited for emergency-service.

A court's internal table of duties supplements the statutory provisions on judicial competence down to the level of determining specific judges ${ }^{53}$. Since the table of duties performs the same function as statute, it must follow the same criteria that are applicable for statutory regulations, i.e. written form and a generalised objective determination of the competences ${ }^{54}$. The parties must be able to obtain information regarding the manner in which the duties have been allocated ${ }^{55}$. Accordingly, the "table of duties" is laid out for inspection in the registry.

Barbey, supra note $24, \S 74$ at no. 52. For criminal proceedings see $\S \S 29,76,122$ GVG which allow the respective courts to a certain degree to determine the number of judges which shall decide, depending on the complexity and difficulty of a case; compare Roth, supra note 17, 175, 230.

This has found expression in the principle of organisational separation between administrative authorities and courts which emanates from the separation of powers doctrine; Classen, in: v.Mangoldt/Klein/Starck, supra note 19, Art. 97 Abs. 1 at no. 4. 
The criteria for the assignment of duties can differ as long as they are objective in nature and established in advance. The first letter of the surname of the accused or the defendant is, for example, a criterion predominantly used in criminal proceedings ${ }^{56}$. Other possible criteria on which allocation can be made are the file number, the date of receipt at court, the field of law, the applicable legal norm ${ }^{57}$ or the area of jurisdiction in which the case was previously heard ${ }^{58}$. An allocation that is determined by the scope of the case is, however, inadmissible ${ }^{59}$. Allocations according to the first letter of the plaintiff's surname pose the problem that they create scope for manipulation by a plaintiff if several plaintiffs are bringing an action. This scope is limited, however, as German law generally prohibits actions on behalf of other persons (Verbot von Popularklagen $)^{60}$.

The question of whether the determination of the reporting judge falls within the scope of the guarantee of the "lawful judge" in Article 101 (1) sentence 2 Basic Law is contentious ${ }^{61}$. Although from a legal point of view the reporting judges only perform a preparatory function ${ }^{62}$ and all the judges involved remain accountable for the decision, an application of the principle of objective determination to the choice of reporting judge is desirable, if one considers the reporting judge's factual influence upon the decision-making process ${ }^{63}$. The table of duties must therefore also lay down a fixed sequence of reporting judges. It is also questionable if lay assessors are subject to the same requirements of selection. However, their adjudicative function - they decide on matters of fact, their vote in the judgment having the same weight as those of professional judges - demonstrates the same need for

This is the predominant criteria used by courts of first instance, compare Kissel, supra note 54, $\S$ $21 \mathrm{e}$ at no. 150. For the case of several accused or defendants, a regulation must exist to prevent a manipulation by the prosecuting authority which decides upon the order of names in the written accusation.

Provision must then be made for the case of collision of norms.

BVerfG (Plenum), NJW 1997, 1497 (1498); Katholnigg, Zur Geschäftsverteilung bei obersten Gerichtshöfen des Bundes und innerhalb ihrer Senate, NJW 1992, 2256.

Katholnigg, supra note 58, 2256.

60

The plaintiff himself must have a right against another person (civil proceedings) or be violated in his own subjective right (public law proceedings).

61 See BVerfG (Plenum), NJW 1997, 1497 (1498) and BGH (VGS), NJW 1994, 1735 (1738)

His task is to prepare the files, present the case and draft the judgment, Roth, supra note 17, 184.

The reporting judge is the first to vote in a decision. Due to high workload often only the reporting judge and the presiding judge are familiar with the files in detail; the other assessors are thus to a large degree dependent on the furnished facts. This advantage in knowledge is limited, however, by the principle of oral proceedings. Compare Roth, supra note 17, 37; Wiebel, Die Bestimmung des Berichterstatters - Eine verfassungsrechtliche Überlegung zur Praxis in den Zivilsenaten des Bundesgerichtshofes, BB 1995, 1197 (1200); also Katholnigg, supra note 58, NJW 1992, 2256 (2258). Yet, the majority opinion in Germany is taking a contrary view. 
independence. The participation of lay assessors should therefore also be stipulated in objective rules ${ }^{64}$.

The decisive criteria for determining the compatibility of a table of duties with Article 101 (1) sentence 2 Basic Law is the extent to which the possibility of manipulation is excluded $^{65}$. Since the allocation of duties within the court is made in advance for the following court year, there is very little room for manipulation by the allocating board. Even if certain judges are known to exhibit a certain tendency in their opinions, this can hardly result in the presiding committee manipulating the outcome of a case to obtain a desired result. Additionally, the danger of manipulative allocations within a court is to a large extent excluded by the fact that the presiding committee is a democratically chosen board, elected by judges ( $\$ 21$ b GVG). Within this board, the court president does not have any leadership status, but acts as an equal member of the board with the same vote as the other members 66 .

By allocating matters to adjudicating bodies on the basis of the areas of law involved, the specialization of judges in their specific areas of expertise is enhanced. In the end, this also takes account of the fact that the law is becoming increasingly specialised.

When only the number of judges which is legally required for a decision is allocated to an adjudicating body - i.e. "normal staffing" - it is then apparent exactly which judges will hear the case. However, in the case of "over-staffing" - i.e. when more judges are appointed to an adjudicating body than is necessary - it is not so apparent which specific judges will hear any particular case. To ensure the efficiency of the judiciary, adjudicating bodies are usually overstaffed with more judges than the law actually prescribes. On the one hand, this enhances uniformity of jurisprudence ${ }^{67}$, on the other hand, it allows for the possibility of substituting judges within the same adjudicating body in cases of leave or illness. The practice of "overstaffing" is today generally regarded as constitutional ${ }^{68}$ and necessary for an organized administration of justice. As a consequence, however, the exact

Roth, supra note 17, 199 ff., 206.

Kunig, in: von Münch/Kunig, supra at note 18, Art. 101 at no. 38.

A direct appeal against the table of duties is not possible. The concerned judges can apply for the declaration of the administrative court whether the table of duties is legally binding for them (Feststellungsklage in terms of $\S 43$ VwGO), Kissel, supra note 54, $\S 21 \mathrm{e}$ at no. 121.

Overstaffing avoids the dividing-up of the same subject matters among several court divisions, Sowada, supra note 19, 261.

Sowada, supra note 19, 260 f.; Kissel, supra note 54, § 21e at no. 129. 
composition of the bench in a particular case is no longer obvious simply by virtue of the fact that the case is allocated to a particular adjudicating body. It is therefore necessary to establish - in a third step - objective principles for determining which judges are to participate in a particular decision ${ }^{69}$. The requirements of article 101 (1) sentence 2 Basic Law are implemented in $\S 21 \mathrm{~g} \mathrm{GVG}$ :

$\S 21 \mathrm{~g}$ [Allocation within the adjudicating body]

(1) Within an adjudicating body that is composed of several judges, the duties are allocated to the members on the basis of a decision by all professional judges that belong to the adjudicating body.

(2) The decision determines, prior to the beginning of the court term and for its duration, the principles in accordance with which the members of the body will participate in the proceedings; it can only be amended if this becomes necessary as a result of overload, insufficient employment, transfer or permanent leave of specific members of the body.

$[\ldots]$

(6) Before the decision-making, the professional judges that are affected by the decision must be given opportunity to comment.

(7) $\S 21$ e (9) applies mutatis mutandis.

The principles of participation are established by the judges themselves. This is again an act of judicial self-management. For this purpose, so-called working groups are established within the adjudicating body, which consist of a legally-prescribed number of judges for the types of cases falling into the competence of the respective adjudicating body. Each group has a different reporting judge. The table of duties determines in which sequence the working groups come together. The registrar of a court allocates the cases successively to the respective working groups according to the order of receipt ${ }^{70}$. A proper allocation of cases according to the sequence of their registration naturally relies on the integrity of the

The application of the principle to the level of single judges has been established in an authoritative decision of the plenum of the Federal Constitutional Court (FCC) in 1997, BVerfG (Plenum), NJW 1997, 1497. This put an end to the disunity among the two senates of the FCC about the admissibility of discretionary determinations of the presiding judge from case to case. See for the opinion of the $2^{\text {nd }}$ Senate: BVerfGE 18, 344 (352); 22, 282 (286); 69, 112 (120 f.), as opposed to the $1^{\text {rst }}$ Senate: BVerfG, NJW 1995, $2703 \mathrm{ff}$. It is insufficient if court-internal rules assign judges to specific dates of court sessions and the concrete allocation is effected through the setting of a date for the cases. This would leave the presiding judge with an avoidable scope of discretion; BVerfGE 95, 322 (331); BVerfG (Plenum), NJW 1997, 1497 (1498). Roth, supra note 17, 191.

The order of receipt of the files at the court is determined not only by the date on which a file was received (indicated by a date stamp), but also by the order in which the file was received on that particular day in relation to the other files (indicated by a sequential order number next to the date stamp). Upon receipt of a case in the registry, the registrar of the court notes down the competent reporting judge and finally submits the case to the presiding judge of the competent adjudicating body. 
postal officer and the registrar at a court. There is only room for manipulation if either of them delays the registration of a case ${ }^{71}$.

\section{The situation in South Africa}

\section{Role of the judiciary during apartheid}

The South African legal system has undergone a legitimacy crisis ${ }^{72}$. An immense loss of confidence in the judiciary took place as a result of the role the courts played in the enforcement of laws during apartheid. Although under the constitutions of 1961 and 1983 the courts were in a comparatively weak position due to sovereignty of parliament, the predominant opinion today is that even under the circumstances of that time the judges could have contributed more, especially towards the protection of the human rights ${ }^{73}$. Even though they were formally independent and impartial, some judges were an integral part of the system of injustice ${ }^{74}$. The majority of the population therefore saw the judiciary as part of the state machinery rather than an independent power committed to the idea of justice ${ }^{75}$. "Political appointments" of judges contributed to the general notion that the whole legal order was part of the system of oppression and exploitation ${ }^{76}$. It is alleged that judges substantially failed to fulfil their task as guardians of justice during apartheid ${ }^{77}$. In addition, the personal composition of the bench - mostly highly-educated white males - was not representative of the majority of the population. The atrocities of the system were underpinned by the legal order. Apartheid can be seen as another example of how legal norms

Such an experience is illustrated by Katholnigg, supra note 58, NJW 1992, 2256, where it occurred that one of the judges asked the registrar to wait with the registration of a specific case until a certain judge was next in line for the respective file number.

Cameron, A 'Single Judiciary'?: Some Comments, SALJ 117 (2000), 141 f.; Fedtke, supra note 5, 422; van der Westhuizen, The protection of human rights and a constitutional court for South Africa: some questions and ideas, with reference to the German experience, De Jure 1991, 1 (5); Kruger, A Constitutional Court for South Africa, Consultus 1993, 13 (14).

Compare Fedtke, supra note 5, 422; van Blerk, Judge and be Judged (1988), 148.

Dyzenhaus, Hard Cases in Wicked Legal Systems, South African Law in the Perspective of Legal Philosophy (1991), 50.

Fedtke, supra note 5, 422.

76

Van der Westhuizen, supra note 72, 5; Kruger, supra note 72, 14. The appointment of Chief Justice Steyn in 1959 marked the start of what is described as the Supreme Court Appelate Division's "cordial relationship with the executive authorities", compare Forsyth, In Danger for their Talents, A study of the Appellate Division of the Supreme Court of South Africa from 1950-80 (1985), 57. Cameron, Nude Monarchy: The Case of South Africa's Judges (1987) 3 SAJHR, 338 with further references; Corder, Judges at Work, The Role and Attitudes of the South African Appellate Judiciary 1910-1950 (1984), 14.

Corder, Judges at Work, supra note 76, 232. 
could be used to create divisiveness, violence and lawlessness, and how a system that constituted a crime against humanity could be upheld by the legal order ${ }^{78}$. The fact that no repentance for past judicial misdeeds has ever been shown, only served to increase the lack of confidence in the judiciary. There was strong criticism of apartheid-era judges who declined to attend the hearings of the Truth and Reconciliation Commission under the pretext of their judicial independence ${ }^{79}$.

\section{Recent developments in the administration of justice}

Today the notion still prevails that the South African judiciary does not entirely exhibit the independence presupposed in section 165 of the Constitution ${ }^{80}$. The already-mentioned report of the UN-commissioner on Human Rights, which strongly criticised key elements of the independence of the South African judiciary, confirmed this perception ${ }^{81}$. This open criticism from an independent institution has incited discussion among South African lawyers about the legitimacy of the judiciary.

With the establishment of the new Constitution, some significant changes have taken place with regard to the independence of the judiciary. Today, judges are no longer appointed by the President on the advice of the Minister of Justice, but on the recommendation of the Judicial Services Commission which has a broad spectrum of representatives from the legal profession $^{82}$. Contrary to the situation previously, the appointment procedure is now public. In this way the important power of appointing judges is subject to more control and no longer simply lies in the discretion of the executive. A decisive factor for the promotion of judicial independence is that judges have security of tenure. They can only be dismissed by a decision of parliament (section 177 of the Constitution). Their remuneration is stipulated in the Judges Remuneration Act. Although they are paid by the state, they are not civil servants ${ }^{83}$. They serve until the age of 70 and receive a relatively high pension. The possibility of manipulation or bribery of judges is thus minimised. This is different with regard

Compare Asmal, in: Dyzenhaus (ed.), Truth, Reconciliation and the Apartheid Legal Order (1998), viii; Robertson, The participation of judges in the present legal system, in: Corder, Democracy and the Judiciary (1989), 72.

Compare Asmal, supra note 78, ix.

80 Fedtke, supra note 5, 422; van der Westhuizen, supra note 72, 5; Kruger, supra note 72, 14.

81

Supra note 9.

82

Section 174 (6) of the Constitution. The composition and functions of the Commission are regulated in section 178 (1) of the Constitution. See for an assessment of the work of the JSC: Malleson, Assessing the performance of the judicial service commission, SALJ 116 (1999), $36 \mathrm{ff}$.

Only magistrates have traditionally had the status of civil servants. Today they are mostly recruited from outside the civil service, compare Cameron, supra note 72, 149. 
to magistrates - the judges of the lower courts of first instance - whose transfer and dismissal is not subject to the same stringent criteria as for judges ${ }^{84}$.

Presently, a unification of the two "branches" - judges and magistrates - is being discussed $^{85}$. Initial steps to exert more control over judges and their decisions have been undertaken in the form of a proposal for a procedure on how to discipline judges ${ }^{86}$. The issue of executive interference with the judicial function came to the fore when the Minister of Justice, Penuell Maduna, asked the President of the Constitutional Court Arthur Chaskalson to continue his service after turning 70 in November $2001^{87}$. Although a prolongation of the term was, in this case, made possible through an amendment of the Constitution $^{88}$, the discussions which accompanied this act highlighted the importance of adhering to the legally-prescribed procedures of appointment, especially with regard to the "political status" and influence of Constitutional Court judges 89.

The areas particularly susceptible to the exertion of influence from outside - the appointment and a prolongation of the tenure of judges - should be treated with special caution ${ }^{90}$.

See section 13 (3)(a) of the Magistrates Act and regulation 22. This as well as other problems of the independence of magistrates were pointed out in a judgment by Southwood J, High Court of South Africa, Transvaal Provincial Division, 2001-06-05 case no A 932/98. Some of these aspects were upheld by the Constitutional Court in its judgment Van Rooyen and others $v$ State and others, CCT 21/01, 2002 (5) SA 246 (CC); 2002 (8) BCLR 810 (CC).

See Cameron, supra note 72; Thring, Comment on the white paper on the judicial system: chapter on the Judiciary produced by the Policy Unit, Department of Justice, SALJ 116 (1999), $858 \mathrm{ff}$.

Department of Justice, working paper on a complaints mechanism against judges, prepared by the Harms Committee. Also see the response from judges of the higher courts: Proposals for a Mechanism for Dealing with Complaints against Judges, and for a Code of Ethics for Judges, (2000) 117 SAJL, 377.

See Mail \& Guardian of 24.8.2001, p.2. Contrary to other judges, judges at the Constitutional Court have a limited tenure (section 176 of the Constitution).

Effected through the Constitution of the Republic of South Africa Amendment Act 34 of 2001 (which also effected a change of the title of President of the Constitutional Court to that of Chief Justice) together with the Judges' Remuneration and Conditions of Employment Act 47 of 2001.

The Constitutional Court makes the final decision on the constitutionality of Acts of Parliament (sections 167 (5) and 172 of the Constitution). In this way it exercises a strong control of the legislative.

90

A negative example is the case of former Chief Justice Rabie. Instead of leaving the bench when having reached the retirement age of 70, the previous chief justice stayed in office as an "Acting Chief Justice" although actually there was no other judge he was acting in behalf of. This was clearly against the provisions of the Supreme Court Act and raised the suspicion that his appointment was guided by the expectation that he was the judge who best represented the government's interests. See Cameron, supra note 76, 34; van Blerk, supra note 73, 142. 
In this regard the principle of the "lawful judge" would provide clear rules as to how the change in office at the end of the term of a constitutional court judge is to be effected ${ }^{91}$.

At present, an overall transformation of the judiciary is being planned by the Department of Justice. A draft strategic plan, "Justice Vision 2000", aims "to create a system which is cheaper, simple, more effective, efficient and generally fair" ${ }^{92}$. The goal with regard to courts is to ensure, amongst other things, that they are "predictable in function" and "fair". This can be taken as a point of departure for the establishment of the principle of the "lawful judge".

After the end of apartheid, South Africa has a particular need to justify the exercise of state power and to avoid any suspicion of its abuse or manipulation. During the deliberations on a transformation of the judiciary the existing practice of allocation of cases should in particular be re-assessed. Only a judiciary that is completely independent can regain the public confidence that it deserves.

\section{Allocation of cases in South African courts}

South Africa belongs to the family of "mixed legal systems" 93 . Its substantial law was originally derived from Roman-Dutch law; but the subsequent influence of English law has led to a mix of different legal norms and traditions. Its entire procedural law, on the other hand, originates from English law. The concept of the "lawful judge" is not part of the legal system. The rules of jurisdiction only determine which is the competent court to decide a matter; the jurisdiction of the superior courts (i.e. the Constitutional Court, the Supreme Court of Appeal and the High Courts) is regulated in the Constitution ${ }^{94}$ and that of the special and lower courts in the applicable statutes ${ }^{95}$.

See for the problem of extended terms of constitutional court judges in Germany: Rüthers, Nicht wiederholbar! Selbstverlängerte Amtszeiten am Bundesverfassungssgericht?, NJW 1996, 1867 (1869); Höfling/Roth, "Ungesetzliche Bundesverfassungsrichter?" - Zur Geltung des Art. 101 Abs.1 S.2 GG für das Bundesverfassungsgericht, DÖV (Die Öffentliche Verwaltung1997, 67 (69). See foreword of the Draft Strategic Plan for the Transformation and Rationalisation of the Administration of Justice, www.gov.za/reports/1996/justice.htm.

Palmer, Mixed Jurisdictions Worldwide, The Third Legal Family (2001), $35 \mathrm{ff}$.

94

95

Sections 167-173 of the Constitution; section 19 of the Supreme Court Act 59 of 1959 for the general jurisdiction of the High Courts.

E.g. sections 157 and 173 of the Labour Relations Act 66 of 1995, section 22 of the Restitution of Land Rights Act 22 of 1994, section 83 of the Income Tax Act 58 of 1962, section 37 of the Competition Act 89 of 1998, section 13 of the Consumer Affairs Act 71 of 1988, section 20 of the Electoral Commission Act 51 of 1996, the provisions of the Magistrates' Courts Act 32 of 1944, Black Administration Act 38 of 1927. 
Personal interviews with judges of the South African Constitutional Court and the Cape High Court confirmed that fixed rules for the allocation of cases do not exist. The whole process of preparation of a case and the identifying of the issues involved, lies in the hands of the advocates and attorneys who act on behalf of the parties. In civil law proceedings, for example, the summons is first taken to the registrar, who issues it on behalf of the plaintiff, and it is then served by the sheriff of the court on the defendant. This is followed by the defendant's response and the subsequent exchange of the pleadings among the parties. All documents are kept in files in the registrar's office. Only when the case is ready for trial will the judge president allocate the case to one or more judges. The procedure of allocation usually takes place at a weekly meeting, when the president determines which judge is to decide which case ${ }^{96}$. In the absence of an objective mechanism, the judge president follows tradition, custom and common sense when allocating the cases. Unlike in Germany, no fixed adjudicating bodies exist at the courts, and the bench is therefore composed freely from among the judges for each case. An additional difference is that South Africa generally does not have Germany's system of specialised courts ${ }^{97}$. It is therefore common practice that the judge president allocates cases to judges who have acquired a certain expertise in the area of law concerned, and who are more experienced in that particular area than their colleagues ${ }^{98}$.

Furthermore, at a High Court the president can individually alter the number of judges who decide a case. His discretion is guided by the importance and complexity of the matter (section 13 (3) Supreme Court Act ${ }^{99}$ ). The number of judges which make up an adjudicative body, be it three, four or five, can be of significance, however. Since the internal process to find consensus differs when more judges participate in the decision-making, the number of judges can potentially influence the outcome of a case.

The South African equivalent to the German practice of "over-staffing" is the appointment of acting and temporary judges (section 175 of the Constitution). These judges are assigned to replace a judge for a certain period of time in case of a vacancy or absence of a judge. If the length of a particular case is expected to exceed the term of appointment of an acting judge, he would most probably not be allocated to it.

Thus, in the South African system, the judge president exercises great influence throughout the process of allocation. Although the judges have the possibility to complain about arbi-

96

99

This is, for example, the case at the Cape High Court where cases are allocated every Friday.

Palmer, supra note 93, 36.

At the Supreme Court of Appeal, for example, the judges that decide a case (usually five) are "picked out of a pool" of 17 judges.

Supreme Court Act, No. 59 of 1959. 
trary allocations, there is no actual mechanism to control the motives that guided the president's decision.

The aim of this practise of ad hoc allocation is purportedly to achieve a fair distribution of workload amongst the judges and to ensure efficient and cost-saving administration of justice. It is not only intended to ensure that cases are decided by particularly capable and experienced judges, but that a speedy trial will take place. Depending on the present workload of a judge, the judge president will generally rather decide to allocate a case to a colleague who is able to finish it within shorter time. This system of case-to-case allocation can also take into consideration the period of leave of judges and the presence of acting and temporary judges ${ }^{100}$. The whole process of allocation thus lies at the discretion of the judge president. The mechanism for the recusal of judges ${ }^{101}$ is the only form of check and balance on this discretion.

Thus, in contrast to the German system, the allocation of judges in South Africa is not regulated by law, but it is left to the discretion and subjective evaluations of the judge president. It is, to a large degree, dependent on the judge president's personal integrity and fairness. Although the allocation of cases may, in the majority of situations, be effected according to the proper exercise of the judge president's discretion, this method leaves a scope for attempts to manipulate the outcome of cases through purposive allocation.

\section{Evaluation}

\section{Reasons for the non-reception of the principle in South Africa}

As pointed out above, the legal system of South Africa is characterised by the fact that it combines different legal traditions. On a foundation of Roman-Dutch law, English procedural and substantive law was imposed, as a consequence of the English influence during their colonial rule of South Africa. This has led to a mixed or "hybrid" legal system ${ }^{102}$. In addition, a third type of law operates in the form of the traditional customary law of the

100 At the Cape High Court there are currently 26 full time judges, some of which are on long leave; they are assisted by 5 temporary and acting judges.

A judge usually applies to recuse himself as a matter of courtesy, or he is asked to recuse himself on the basis that he does not possess the necessary distance from a case or party. If he refuses to recuse himself, this decision can be appealed to a court of higher instance. For the procedure of recusation of judicial officers see Erasmus, in: Jones and Buckle, The Civil Practice of the Magistrates' Courts in South Africa, vol. I, $8^{\text {th }}$ ed. (1988), $19 \mathrm{f}$.

Palmer, supra note 93, $35 \mathrm{ff}$. 
indigenous African tribes ${ }^{103}$. The difficulty for the new Constitution was - besides the immense social divisions that exist - to create a new legal order that takes this development into consideration and reconciles the different traditions of law. Both the interim Constitution of 1994 and the Constitution of 1997 show elements of having received legal norms from other countries that were adopted during the constitutional process. This "borrowing" from foreign legal institutions by way of reception is a general cultural phenomenon which can assist the receiving country to benefit from other countries' experiences ${ }^{104}$. In this way, foreign concepts are able to enter into the legislative process and into the jurisdiction and jurisprudence of a country ${ }^{105}$. The German Basic Law provided the example of a democratic state order, based on the guarantee of human rights. Its concepts and structure served, to a considerable extent, as a model for the new South African Constitution. In particular, the bill of human rights, the federal structure (to a certain degree) and the concept of a separate Constitutional Court with special jurisdiction exclusively over constitutional matters were taken from the German model ${ }^{106}$. Different traditions of court structure and organization may have been the reason for the non-reception of the principle of the "lawful judge".

Due to the traditional common law influence, South African procedure, especially in the higher courts, follows the English tradition ${ }^{107}$. The English legal system fails to acknowledge, either in statutory or unwritten law, a principle that nobody shall be deprived of his legally-competent judge. As in South Africa, the allocation of cases is undertaken as a "matter of convenience", allowing manifold discretionary decisions ${ }^{108}$. The legal system provides no safeguards against manipulations of the selection or composition of an adjudicative body or manipulation of the allocation of duties within a court ${ }^{109}$.

103

Customary law has regained recognition in sections 31, 35 (3) and schedule 4, constitutional principle XIII of the interim Constitution; now its respect is guaranteed in sections 39 (3) and 211 f. of the 1997 Constitution.

Fedtke, supra note 5, 16; also compare Watson, Legal Origins and Legal Change (1991), 73.

106

Fedtke, supra note 5, $43 \mathrm{ff}$.

See Mostert, The Constitutional State, the Social State and the Constitutional Property Clause, ZaöRV 61 (2002), 346 (347ff.); de Waal, A Comparative Analysis of the Provisions of German Origin in the Interim Bill of Rights, 1995 SAJHR, $1 \mathrm{ff}$.

As in England, the practice is divided into advocates (barristers) and attorneys (solicitors), Hahlo, National Reports: South Africa, International Encyclopedia of Comparative Law, vol. I, S-78.

Henkel, England - Land ohne "gesetzlichen Richter" (1971), 16, 37.

See the as of yet unpublished historical and comparative analysis of the "lawful judge" in Germany, England and France by Seif, Recht und Justizhoheit, Historische Grundlagen des gesetzlichen Richters in Deutschland, England und Frankreich. 
In South Africa the discretionary allocation of cases to particular judges by the judge president has never been perceived as a problem. This may also be explained by the fact that most judges are appointed from the ranks of senior practising members of the $\mathrm{Bar}^{110}$. As opposed to their counterparts in Germany, judges in South Africa are not career judges. The appointment of long-serving, experienced judges generally enhances public confidence in the judicial function ${ }^{111}$.

One reason for the non-adoption of the principle of the "lawful judge" during the drafting of the new Constitution might therefore have been a lack of awareness of the problems that arise in respect of discretionary allocations. Since the English-influenced procedural law did not recognize a similar notion, the practice of discretionary allocation was not perceived as being problematic for the independence of the judicial process. This might also be explained by the different role a judge plays in the common law system; as opposed to judges in civil law systems who play a more active role in the course of proceedings, the common law judge only comes into the proceedings at a later stage. He is less involved in administration and management of cases in comparison to his civil law counterparts. The present system of allocation has purportedly served well over a long period of time and has apparently never attracted serious criticism. The flexibility and discretion allowed to the court president was accepted as necessary for an efficient administration of justice.

Reception of specific norms (as opposed to a comprehensive mass reception) is always faced with the problem of integrating such norms into an existing mosaic of historically grown and coordinated norms and adapting them accordingly ${ }^{112}$. The German court system only served as a model for the creation of South Africa's Constitutional Court. The structure of the ordinary courts in South Africa still follows the English tradition. Traditionally, specialized courts do not exist; instead the common law tradition of unitary courts without institutional separation or subject matter distinction is adhered to ${ }^{113}$. However, a tendency towards creating specialised courts and tribunals can be seen today in South Africa ${ }^{114}$. The

110

Hahlo, supra note 107, S-78; Palmer, supra note 93, 37.

112

Compare Corder, supra note 76, 23.

113

Fedtke, supra note 5, 16.

Palmer, supra note 93, 36.

114

Spezialised courts have, for example, been established for certain branches of law such as Water Courts in terms of the Water Act 54 of 1956; the Special Court for Hearing Income Tax Appeals created by the Income Tax Act 58 of 1962; Small Claims Courts established by the Small Claims Court Act 61 of 1984; the Industrial Court established in terms of the Labour Relations Act 28 of 1956, which has now been replaced by the Labour Court, established in terms of the Labour Relations Act of 1995; the Land Claims Court established in terms of the Land Reform Act 3 of 1996. In matters relating to patents, a judge is deputed to sit as a Commissioner of Patents. See Loots, in: Chaskalson/Kentridge/Klaaren/Gilbert/Spitz/Woolman (eds.), Constitutional Law of South Africa, up to date as at 30 June 1999, 6-30 note 4. 
enacting of new statutes for special courts and special tribunals creates a tension with the common law principle of courts of general jurisdiction and the principle of inherent jurisdiction of superior courts ${ }^{115}$. Considering the increasing specialization of the law, the creation of specialized courts is likely to continue in South Africa, despite the tensions that this creates in a mixed legal system ${ }^{116}$.

\section{b) Comparative survey and international law}

A comparative survey shows that other countries do not have an "institution" comparable to the "lawful judge" in Germany. Some countries do have a similar principle, but this involves only the guarantee of a legally established, independent court, not the guarantee of objective determination of a particular judge ${ }^{117}$. The potential danger that broad rules for the recusal of judges pose for judicial independence has recently been highlighted in Italy by the criticism of the latest legislation regarding the moving of cases to other jurisdictions and the recusal of judges. Other countries that are undoubtedly governed by the rule of law do not have a guarantee of the "lawful judge" or "legally-established court" at all ${ }^{118}$.

International law also does not require regulations governing the manner in which court cases are allocated to particular judges. International standards mostly focus on the personal independence of the judges and their freedom to decide in accordance with their legal conviction. The UN Basic Principles of an Independent Judiciary speak of the competence of the "judiciary [...] as defined by law" and provide that "tribunals that do not use the duly established procedures of the legal process shall not be created to displace the jurisdiction belonging to the ordinary courts or judicial tribunals"119. Article 10 of the Universal Declaration of Human Rights enshrines the right to a fair and public hearing by an independent and impartial tribunal. Section 6 (1) of the European Convention on Human Rights only entitles a person to have its case decided by an independent and impartial court that is established in terms of statute.

Only in Austria does there exist an express obligation on the courts regarding the internal allocation of responsibilities. In France norms that empowered the president to determine competent judges have been declared as unconstitutional. Classen, in: v.Mangoldt/Klein/Starck, supra note 19, Art. 101 at no. 15; Kunig, in: von Münch/Kunig, supra note 18, Art. 101 at no. 2

118 This is, for example, the case in Denmark, Sweden and the United States; compare Classen, in: v.Mangoldt/Klein/Starck, supra note 19, Art. 101 at no. 15 , note 30. in: The Judicial Officer, 25 vol 2 no 1 (June 1999). 
The application of the principle down to the level of determining specific judges is therefore a unique notion. It finds its justification in the apparent need to safeguard the independence of the judiciary after the abuse of state power and the circumvention of existing legal rules in the period of National-Socialism in Germany.

\section{Flexibility versus certainty of the law}

Germany and South Africa's different legal traditions have apparently led to opposite conceptions of the precision with which judicial competence must be determined. On the one hand stands the "lawful judge", determinable by means of objective criteria - on the other hand the "arbitrary judge", who can be determined in a more flexible and discretionary manner. The problem of allowing discretion in the allocation process must be seen against the following background: providing the judge president with a wide degree of discretion creates a greater flexibility to react to specific circumstances. The discretionary element is thereby in theory able to enhance the efficiency of the legal process by using the resources in an optimal way. But is substantial justice really enhanced by this practice? Should not a plaintiff be able to reasonably expect that his case is allocated to a judge without regard to the specific facts? Does this not rather create the danger of the character of a particular judge having a dominant influence on proceedings?

This tension between ensuring justice in a particular case (Einzelfallgerechtigkeit) and ensuring legal certainty (Rechtssicherheit) is a typical example of the interplay of constitutional values and the possible conflicting interests that may arise. However, goal of ensuring an efficient judiciary should not be achieved at the expense of fundamental procedural rights. The rule of law rather intends to achieve efficiency of justice, whilst still complying with the procedural guarantees granted by the constitution ${ }^{120}$.

An objective predetermination of who will judge a particular case also functions as a means to compensate for human imperfection and the influence of personal preconceptions on a decision. Judges are not mere machines that deliver justice ${ }^{121}$. Even with the application of common techniques of interpretation, the outcome of a case is more or less consciously influenced by the personality of the specific judge ${ }^{122}$. The judge's preconceptions affect not only the assessment of the facts of a case, but also the ensuing legal evaluation of such facts. At the end of the day, a judicial decision is also dependent on the moral views,

\footnotetext{
120

Compare Degenhart, supra note 19, § 75 at no. 23 .

121 Compare BVerfG, NJW 1995, 2703 (2704).

122 BVerfG, NJW 1995, 2703 (2704).
} 
emotions, intelligence and prejudices of the designated decision-maker ${ }^{123}$. Against this background it is evident why a specific judge cannot simply be replaced by another. No system of allocation is capable of entirely excluding the influence of personal preconceptions upon a judgment. As a consequence, parties in judicial proceedings must be provided with a right that "their" judge is not purposively determined or arbitrarily exchanged. It is true that individual decisions of allocation from case to case offer the possibility of taking into account both the individual capacity and experience of judges, and the urgency of a matter. But the right to fair proceedings, as an element of the rule of law doctrine, requires that the determination of a "competent judge" must be made in accordance with a system that prevents the possibility of allocating particular cases on the basis of a judge's personal dispositions. The judge president should not become a "master of the judges" 124 . Instead, the "competent judge" must be chosen without regard to the subject matter of the case or the persons involved, as if "blindly" 125 .

The fact that the judge president may be guided exclusively by objective and impartial motivations is irrelevant. Trusting in the integrity of the judge president is not a sufficient safeguard against manipulation. The mere possibility that members of a court may be chosen because they exhibit a particular tendency should be prevented from the very outset $^{126}$. The principle of objectiveness of allocation - in the sense that the process is guided by objective principles - represents the procedural compensation for the individual nature of each decision. The randomness of the process by which the "lawful judge" is selected thus functions as a constitutional safeguard to enhance procedural fairness ${ }^{127}$. Objective rules of competence further enhance transparency in the administration of justice and thereby also contribute to the credibility of the judiciary.

The chances for a potential abuse of the system for personal motives - e.g. in the case of urgent matter applications ${ }^{128}$ - must be considered as being low. Even though manipulation

Compare Leisner, Gesetzlicher Richter - vom Vorsitzenden bestimmt? Problematisches Richterrecht aus den Vereinigten Großen BGH-Senaten, NJW 1995, 285 (286).

BVerfG (Plenum), NJW 1997, 1497 (1498)

Compare for the Basic Law the report on the Constitutional Convent on Herrenchiemsee (1948), commenting part p. 93, Art. 131: "Extraordinary courts are those that are established by the government or the executive for particular single cases or groups of single cases, which entails the danger or the suspicion that the members of the court with a particular tendency are chosen. In contrast to this stands the "lawful judge" that is determined through abstract norms and thus without regard of the person involved."

Berkemann, Anmerkung zu BVerfG, Beschluß des Plenums vom 8.4.1997, JR (Juristische Rundschau) 1997, 281 (282).

An attempt to circumvent the jurisdiction of a particular judge was apparently undertaken in the recent case of nine rugby players who were accused of murder at the Pietersburg Regional Court. 
in the form of parties choosing when is best to bring their case to court cannot totally be excluded, the potential for an actual influence on the outcome of a case is very limited. The guarantee of the "lawful judge" only provides for an objective and predetermined means of determining the judge, not necessarily his actual determination. The calculation of when to bring the case to court in order to have a case heard by a particular judge will therefore mostly be a matter of chance. After all, the principle of the "lawful judge" seeks to prevent manipulations by the state as bearer of judicial authority - if the procedure of allocation is performed impartially and neutrally, there is no room for the parties to influence the process either.

\section{Deduction of the principle from the Constitution}

A brief analysis of selected constitutional norms will now be undertaken to determine if the principle of the "lawful judge" is implied in the South African Constitution or can be deduced from its underlying values. Yet, such a "reading in" of a meaning into a norm cannot take place without reservations. The traditional approach in the interpretation of statutory law is that words cannot be read into a statute by implication unless the implication is a necessary one, in the sense that, without it, effect cannot be given to the statute as its stands ${ }^{129}$. However, the approach to constitutional interpretation is slightly different. A "reading in" of implied provisions by giving effect to the underlying values of a constitutional norm is recognised as a "unique" technique of constitutional interpretation in the evolution of a constitution $^{130}$.

The independence of the judiciary is entrenched in section 165 of the South African Constitution. Section 165 (2) of the Constitution guarantees the independence and impartiality of the courts. It requires an application of the Constitution and the law by the courts without fear, favour or prejudice. The requirements in terms of section 165 were discussed in De Lange $v$ Smuts $N O$ \& Others:

Four of the accused brought an unexpected bail application while the magistrate allocated to the case had postponed the hearing of the applications due to his absence. The timing of the bail applications raised suspicions after one of the accused had already been denied bail. See the 129 reports in Cape Times of April 25 2001, p. 4 and of April 27 2001, p. 5.

130

Rennie NO v Gordon NNO 1988 (1) SA 1 (A) at $21 \mathrm{E}$.

S v Makwanyane \& another 1995 (3) SA 391 (CC), 1995 (6) BCLR 665 (CC) at para 15; Kentridge/Spitz, in: Chaskalson et al., supra note 114, 11-10. 
"Although there is obviously a close relationship between independence and impartiality, they are nevertheless separate and distinct values or requirements. Impartiality refers to a state of mind or attitude of the tribunal in relation to the issues and the parties in a particular case. The word "impartial" connotes absence of bias, actual or perceived. The word "independent" reflects or embodies the traditional constitutional value of judicial independence. As such, it connotes not merely a state of mind or attitude in the actual exercise of judicial functions, but a status or relationship to others, particularly the Executive Branch of government, that rests on objective conditions or guarantees" 131 .

Objective rules of allocation can play a valuable role in ensuring judicial impartiality. In contrast, allocations on an ad hoc basis do not provide safeguards against potentially-biased judges and prejudiced applications of the law.

Independence of the courts requires institutional independence, i.e. independence in the relationship between the courts and other arms of government ${ }^{132}$. Section 165 (3) of the Constitution protects the functioning of the courts against interference by a person or an organ of state. This provision provides important institutional protection for the courts ${ }^{133}$. The broad term "functioning" implies that this protection also covers internal court procedures such as case allocation. In the recent Van Rooyen case the Constitutional Court pointed out that the test for assessment of judicial independence includes an element of "appearance or perception": it must be taken into account whether a court would be considered independent in the eyes of a notional reasonable, well-informed, thoughtful observer. The Court stresses that this observer

"must be sensitive to the country's complex social realities, in touch with its evolving patterns of constitutional development and guided by the Constitution, its values and the distinction it draws between different levels of courts" 134 .

This assessment takes into account the increased demand for justification of the manner in which judicial power is exercised after the experiences during apartheid ${ }^{135}$. It can be argued that a reasonable observer may perceive arbitrariness in a system that selects its judges on a

O'Regan J, in: De Lange v Smuts, supra note 131, at para 160; Chaskalson CJ, in: Van Rooyen and others $v$ State and others, CCT 21/01, 2002 (5) SA 246 (CC); 2002 (8) BCLR 810 (CC) at para 31.

133 Van Rooyen and others v State and others, supra note 132, at para 18.

134 Van Rooyen and others $v$ State and others, supra note 132, at para 34.

135 The German Federal Constitutional Court has stated in an early decision that the independence of the judiciary is of fundamental importance with regard to the experiences during National-Socialism, BVerfGE 2, 307 (320). The guarantee embodied in section 165 (2) of the South African Constitution fulfils a similar function after the apartheid regime. 
case-to-case basis free from any regulating obligations ${ }^{136}$. The fact that determination is made on an ad hoc basis must appear as arbitrary, even if it is not done in an arbitrary way ${ }^{137}$. Objective principles of judicial selection do not merely have the goal of avoiding arbitrariness in the judicial selection process. They aim at excluding the possibility of arbitrary allocations at an early stage. The mere appearance of undue influence on the adjudicating function ought to be prevented in order to increase the independence and neutrality of the courts - elements that are indispensable for the functioning of the judiciary under the rule of law. If the principle of the "lawful judge" is properly applied, the only remaining possibility to assert undue influence on the judiciary lies in the process of appointment.

The persuasive power of judicial decisions does not rest only upon the quality of their reasoning. It depends to a large extent on public confidence in the courts. The higher the degree of confidence in the objectivity of the judges is, the greater will be the willingness of the public to accept the authority of the courts. This is particularly true in a legal environment such as in South Africa, where the administration of justice had for a period of time been strongly influenced by the executive.

Section 165 (4) of the Constitution contains an obligation for organs of state to assist and protect the courts through legislative and other measures to ensure their independence, impartiality, dignity, accessibility and effectiveness of the courts. In this case, the measure that would have to be taken would involve legislative reform in the area of court administration.

The concept of the "lawful judge" is beneficial to promoting an independent and impartial judiciary. Its major effect - non-interference in the functioning of the courts - is laid down in section 165 (3) of the Constitution. Objective rules of judicial selection that prevent allocations on an ad hoc basis are a prerequisite for an entirely independent and impartial judiciary that is mandated by the Constitution. The existing practice of discretionary allocations from case to case, however, seems to be incompatible with judicial independence.

\section{b) Right to fair trial}

Sections 34 and 35 (3) of the Constitution embody the right to a fair trial. Section 34 of the Constitution guarantees every person the right to have any dispute that can be resolved by

136 See for the German jurisdiction BVerfG, NJW 1995, 2703. Also compare Wiebel, Die senatsinterne Geschäftsverteilung beim Bundesgerichtshof (Zivilsenate), BB 1992, 573 (574), who deems such procedure suited for monocratic structures in the administration, but not suitable for

137 courts composed of several judges.

Compare BVerfGE 82, 286 (298) = NJW 1991, 217. 
the application of law decided in a fair public hearing before a court or, where appropriate, another independent and impartial tribunal or forum. It recognizes a right to fairness in litigation $^{138}$. The concept of a fair trial is rooted in the rule of law doctrine. It requires a standard of independence and impartiality that is implicit in the requirements of natural justice $^{139}$. Fairness of trial therefore does not only include the guarantee to have one's dispute decided by an independent and impartial judge. The term "fairness" further entails the requirement that the whole proceedings are guided by objective criteria, and not arbitrariness. The proceeding does not simply involve the hearing before the court: they encompass the whole course of procedure from the registration of a case at court to the final judgment. Independence of the court and impartiality and neutrality of the judge are prerequisites for a fair and unbiased procedure. Only if these requirements are met, can a judge apply his professional knowledge in the adjudicating process free from undue influences. Only in such circumstances will be parties be guaranteed equality of treatment, on the one hand, and an unbiased examination of the facts and impartial application of the law on the other. Since section 34 entitles a party to a right of access to the independent courts and fair proceedings, it thereby also requires prevention of an arbitrary allocation of the judge in the phase that precedes the actual trial.

Section 35 (3) of the Constitution guarantees the accused the right to a fair trial. The safeguard of such a right is one of the main goals of institutional judicial independence ${ }^{140}$. Judicial impartiality and the application of law without fear, favour or prejudice are therefore seen as inherent in the right to fair trial. Objective rules of allocation create transparency in proceedings and thereby promote the right to a fair trial through public control. This further contributes to enhancing public confidence the judicial process.

Section 35 (3)(c) of the Constitution is directed at a public trial before an "ordinary" court. This provision resembles the prohibition against extraordinary courts in Article 101 of the German Basic Law. The term "ordinary court" can also be understood in the sense that a trial must take place before a court that is established in terms of a law. This provision basically recognizes, therefore, the general principle that a party is entitled to bring his case before the appropriate court, and cannot be denied this right. Read together with the obligation of the state in section 7(2) of the Constitution to respect, protect, promote and fulfil the rights in the Bill of Rights, the guarantee in section 35 (3)(c) of the Constitution can be construed as a positive duty for the legislator to avoid interference with the court procedure. Then the law must establish the criteria for determining which court is appropriate to hear which matter.

Chaskalson, in: Chaskalson et al., supra note 114, 26.2 (b), 26-7. The interim Constitution did not expressly recognize a right to fair trial.

140

Snyckers, in: Chaskalson et al., supra note 114, 27.5 (e)(i), 27-68.

Chaskalson CJ, in: Van Rooyen v State, supra note 132 at para 35. 
Sections 34 and 35 (c) of the Constitution are manifestations of the rule of law doctrine. Further principles that enable public control of the judiciary are the principle of open court $^{141}$ and the obligation of the judge to give reasons for his decision. These are important elements of the guarantee of fair trial, although they aren't the only ones. The idea of a "lawful" court or tribunal has been acknowledged in sections 34 and 35 (3) of the Constitution. Section 35 (3)(c) of the Constitution seems to express the notion that a litigant is entitled to have his case heard by an objectively-selected judge, and cannot be denied this right.

\section{c) Rule of law and separation of powers}

The rule of law doctrine is entrenched in the founding provisions of the South African Constitution in section 1 (c). Its origins lie in a Western understanding of justification and legal control of the exercise of state authority ${ }^{142}$. In the countries where the rule of law was initially developed, the rule of law also comprises the right to an unbiased, impartial and objective judge.

The South African Constitution further recognizes a separation of powers that splits the state authority between the legislature, the executive and the judiciary ${ }^{143}$. The separation of powers doctrine clearly mandates distinct areas of competence in which the other authorities cannot interfere. An independent functioning of each power is a prerequisite for the system of mutual control between the state powers. Only an independent judiciary that is protected against influences and manipulations can fulfil its assigned function in this system of checks and balances. The existence of a mechanism that allocates judges to cases by means of objective criteria without regard to the specific facts or nature of the cases, satisfies the requirements of the rule of law and the separation of powers doctrine.

The necessity of a "lawful judge" in the South African legal system can therefore already be deduced from these general principles.

141 Entrenched in section 16 of the Supreme Court Act.

142 Compare Mostert, supra note 106, $355 \mathrm{f}$.

143

See section 43 for the legislative authority in the national sphere, section 85 and 125 for the executive authority and section 165 for the judicial authority. 


\section{IV. "Justice must not only be done, it must also be seen done" - proposals for a legislative reform}

As has been shown, fundamental principles of the South African Constitution - notably the rule of law doctrine and the guarantee of independent and impartial courts - demand a mechanism of allocation that is not susceptible to manipulation. However, a "reading in" of such a mechanism into the Constitution, in the sense that such mechanism already exists as a constitutional requirement, seems problematic. Tribe's comment on the separation of powers is instructive in this respect:

"[...] it is important not to leap over that [constitutional] text in favour of abstract prin-

ciples that one might wish to see embodied in our regime of separation of powers, but

that might not in fact have found their way into our Constitution's structure"144.

Although the concept of the "lawful judge" would seem to be a natural consequence of a number of key principles in the Constitution that all emanate from the rule of law, the longterm traditions of the South African courts cannot simply be ignored through a "reading into the Constitution" of desired principles for the allocation of cases. To create legal certainty, a positive legal establishment of the guarantee of the "lawful judge" would therefore have to take place.

As the most urgent problems have been addressed during the first years of operation of the Constitution, it is about time to pay attention to accompanying problems. In terms of Item 16 (6)(a) of Schedule Six to the Constitution, all courts, their structure, composition, functioning and jurisdiction, and all relevant legislation, must be rationalised with a view to establishing a judicial system suited to the requirements of the Constitution. In the context of an overall reform of the judiciary the question of how to ensure a mechanism of allocation that cannot be manipulated should not be ignored. Safeguards must be provided against arbitrary allocations of cases in order to prevent even the slightest suspicion of illegitimate influences.

Due to its procedural tradition, the South African system of allocation traditionally claims to need a larger degree of flexibility than the German court system. But the discretion that is exercised at the moment by the judge president is too broad. This practice is not compatible with the guarantee of a fair procedure before independent courts (section 165 of the Constitution) and does not comply with the requirements of the rule of law. If established court practices do not come up with new constitutional standards of judicial independence, they must be revised and adapted to the new requirements.

144

Tribe, American Constitutional Law, vol. 1, $3^{\text {rd }}$ ed. (2000) at 127. Citation: Chaskalson CJ, in: Van Rooyen $v$ State, supra note 132, at para 34. 
To provide an administration of justice that is based on the rule of law the principle of the "lawful judge" should be manifested in a concrete form. Section 165 (3) of the Constitution would be an appropriate place to supplement the rather vague existing provision by adding a further provision, establishing the guarantee to have one's case decided by a judge who is chosen by means of objective statutory norms. The adoption of such a guarantee into the Constitution has the advantage that it would grant the individual an actionable constitutional right. If a codification of the principle does not find its way into the Constitution, it should at least take place on a statutory level. The principle could be incorporated into the statutory regime regulating court organization. Such a statute would have to specify detailed requirements in order to avoid uncertainty in its application. A mere regulation of the process by rules of court practice is not sufficient; the rules governing the recusal of judges also do not go far enough. A party can only assert the right of the "lawful judge" effectively if it is laid down at least at a statutory level.

The traditional common law court structure in South Africa does not make a reception of the principle of the "lawful judge" impossible. The ideal of an all-knowing judge is unlikely to prevail, since it is realized that the common law tradition of courts of general jurisdiction is no longer suitable as a result of the increasing complexity of the law. Lawyers have reacted to this development by specialising in specific fields. This development cannot be ignored by the courts. Yet, even though the South African Constitution contains some "federalistic elements", a complete conversion of the South African system into a federal court structure - as is presently being suggested for the European Union - is too farfetched. Due to the different legal tradition in South Africa, this does not seem realizable and maybe not even desirable. But the German example of specialised court divisions and fixed adjudicating bodies could provide a suitable model in this regard. This could also make the practice of appointing acting and temporary judges, whose status is problematic in view of their independence, dispensable. But a simple introduction of objective principles for the allocation of cases is also possible without an overhaul of the existing court structure.

However, the problem of cost-effectiveness must be taken into account. Provision must be taken that the principle of the "lawful judge" is not used as a justification for unnecessary bureaucracy. Costs can be a decisive obstacle for the majority of the South African population in determining whether to bring their case before the courts and have their rights enforced $^{145}$. Unnecessary waste of money through complicated and superfluous court rules must be prevented. But it is beyond contention that every legal system that is based on the rule of law should limit the scope for discretion to a necessary extent and should be founded on clear rules. A well-conceptualised statutory regulation that still offers a certain 
degree of flexibility can contribute to the efficiency of the judiciary. An increased degree of precision in judicial selection does not, per se, lead to an additional financial burden for the fiscus. However, additional costs will arise from an increasing number of lawsuits for breaches of these new rules. This should be tolerated, however, in the interests of ensuring judicial independence and fair administration of justice.

In my opinion an implementation of the principle of objective case-allocation in South Africa is highly desirable. A judge should not be allocated to a particular case on the basis of arbitrary factors. An application of the principle of the "lawful judge" puts the objectivity of the allocation process beyond all doubt. After all, the exclusion of potential manipulation in the administration of justice can only help a legal system regain the confidence that it needs for its justification and acceptance. This is a prerequisite for the independent functioning of the judiciary in terms of the internationally-esteemed South African Constitution. 